\title{
Should We Consider Expected Environmental Benefits When Planting Larger or Smaller Tree Species?
}

\author{
T. Davis Sydnor and Sakthi K. Subburayalu
}

\begin{abstract}
Ohio, U.S.'s Shade Tree Evaluation Project began in 1965. Two of the original plantings in Brooklyn, Ohio, U.S. included 17 smaller growing, Lavalle hawthorn (Crataegus $\times$ lavallei Hérincq ex. Lavallee) and 84 larger growing thornless honeylocusts (Gleditsia triacanthos L. Sunburst). One consequence of selecting trees is the differing values of environmental benefits generated by trees of various sizes and survival rates. Values of environmental benefits have not been considered in plant selection but the i-Tree free suite of software now allows this to be calculated.

Algorithms recovered from i-Tree Streets were used to calculate environmental benefits in ten, randomly selected trees in each of the two plantings in Brooklyn, and adjusted for survival rates, 89\% survival on Morton Avenue for honeylocusts and 65\% for hawthorns as planted on Orchard Grove. When adjusted for survival, honeylocusts deliver USD $\$ 430$ per tree in benefits in contrast to the $\$ 57$ per tree for hawthorn. When viewed on a per surviving tree basis, honeylocusts provide more than 7.5 times the environmental benefits. Regardless of how it is viewed there is a significant reduction in environmental benefits when using smaller statured trees compared with larger trees. Communities should consider this aspect when space for larger trees is available.

Key Words. Crataegus; Community Forestry; Environmental Benefits; Gleditsia; Hawthorn; Honeylocust; i-Tree; i-Tree Streets; Street Trees; STRATUM; Urban Forestry.
\end{abstract}

Ohio's Shade Tree Evaluation Project (OSTEP) was started in 1965 and originally funded by the state of Ohio, U.S.'s investor owned utilities (Reisch et al. 1971). The original project was in two phases. One phase of OSTEP was a shade tree evaluation plot located in Wooster, Ohio, U.S., where eight replicates of more than 100 taxon were planted in a lawn-like environment and evaluated for growth and development. A second part of the project was to evaluate trees in a streetscape with trees generally growing in tree lawns of various widths. Utility foresters identified tree species (cultivar) that had been recently planted or were planned, and sought permission from the communities to evaluate the trees over time. The trees were maintained as a part of the community's urban forestry plantings. Since planting under utility wires was a concern then as it is now, an emphasis was placed on evaluating a number of smaller species, such as hawthorns (Crataegus sp.), which they thought could be grown under power lines (Reisch et al. 1971). Larger growing species, such as honeylocust were also evaluated because of concerns expressed for biodiversity and for use generally in areas not in conflict with utility lines. A long standing criterion for biodiversity has been the 10-20-30 guideline as articulated by Santamour (1990).

The original streetscape plantings selected for OSTEP included 53 taxa scattered in 97 locations in five Ohio metropolitan areas. Because of various levels of interest among utility foresters and support, more than half of the locations were in the Cleveland metropolitan area, which was the most rapidly growing area in the state during the 1950s and 1960s. Urban foresters needed information on the performance of various tree species then being introduced in order to meet their needs. While larger trees of any species and age are now known to deliver greater benefits than do smaller trees
(McPherson 2005), this was not considered in 1965 by Ohio's utility foresters nor were there tools available to evaluate them.

In order to enable community forest managers to evaluate the community tree resource, the USDA Forest Service introduced i-Tree (Anonymous 2006). i-Tree is a suite of free, peer reviewed software products. One of the programs, i-Tree Streets (formerly known as Street Tree Resource Analysis Tool for Urban forest Managers, or STRATUM), was introduced and was included in i-Tree specifically to evaluate the street tree resource and assumes that trees are individual units and not part of a continuous canopy. Using a sample or complete tree inventory, i-Tree Streets describes tree management needs and quantifies the values of environmental and aesthetic benefits. One limitation of i-Tree is that it uses size ranges when calculating benefits, thus trees in the same size range would have the same benefits. A second limitation is that survival rates are not factored into the $\mathrm{i}$-Tree analysis because i-Tree calculates benefits for surviving trees in the inventory.

The intent of this study was to evaluate the economic benefits being delivered by two species of differing mature sizes when adjusted for varying survival rates after 46 growing seasons in similar sites that remained similar in the streetscape of a community using the community's standard tree maintenance program.

\section{MATERIALS AND METHODS}

\section{Species Selection}

Honeylocust was among the larger growing trees with good survival rates in the earlier OSTEP study and was chosen as the larger tree for comparison (Sydnor et al. 2010). Honeylocust 
cultivars were originally selected by the nursery industry for marketing traits-such as foliage color in the case of Sunburst honeylocust - but overall growth between cultivars within the genus were similar both in the street trials and the research plots (Sydnor et al. 2010). Thus the honeylocust cultivar, Sunburst, was selected to represent a larger tree for the purpose of the study.

Overall, hawthorns had much poorer survival rates in the original OSTEP plantings than honeylocusts, with many hawthorn plantings in the street trials having no survivors after 35 years. However, site conditions were often poorer for hawthorns, which were often planted in smaller tree lawns or sidewalk cuts or had overhead utility lines that would confound comparisons of growth rate and survival for any species. Lavalle hawthorn had the best survival rates in its genus (Sydnor et al. 2010) and was selected as the subject of this study to represent smaller trees. Additionally, community, site similarities, tree maintenance programs, and growing conditions within the community were considered when selecting representative species.

\section{Site Selection}

Two of the 97 plantings in the community portion of the original OSTEP in Brooklyn, $\mathrm{OH}$, were selected for evaluation because of the previously noted site similarities. The Lavalle hawthorn planting was on Orchard Grove Ave. between Parkside and W. 74th St. (Latitude N41 26 '3.60" and Longitude W8144'50.94”). Hawthorns were planted $12-15 \mathrm{~m}$ on center in $2.1 \mathrm{~m}$ tree lawns on both sides of the road and estimated to have been planted in 1964 as $5 \mathrm{~cm}$ trees. A planting of Sunburst honeylocust was located on Morton Avenue between Forest Edge Drive and Outlook Drive (Latitude N41 ${ }^{\circ} 26^{\prime} 45.35^{\prime \prime}$ and Longitude W81 ${ }^{\circ} 44^{\prime} 11.22^{\prime \prime}$ ). Honeylocusts were planted $12-15 \mathrm{~m}$ on center in a $2.4 \mathrm{~m}$ tree lawn on both sides of Morton Avenue with an estimated planting date of 1964 and estimated size at planting of $5 \mathrm{~cm}$.

Homes, tree lawn sizes, building setbacks, and lot sizes on Orchard Grove and Morton were similar, and the two sites are located approximately $1.6 \mathrm{~km}$ apart. Soils were urban complexes of a relatively recent geological origin. Soils on Orchard Grove were an Urban land-Elnora complex (UeA), while soils on Morton were Hornell-Urban land complex $(\mathrm{HsC})$ with urban soils representing $30 \%-70 \%$ of the complexes. Tree maintenance during the ensuing years was performed by Brooklyn city crews as dictated by city maintenance procedures and thus similar. Homeowner maintenance varied as would be expected. Sidewalk repair was more common with the larger growing honeylocusts. One homeowner with honeylocust noted that the sidewalk had been repaired twice since she had lived at her home. The tree lawn widths allowed for root pruning to replace sidewalks without affecting structural stability, in the researchers' judgment. Overhead utility lines were not present in either site, thus no utility pruning was evident.

\section{Analysis Procedure}

Comparison of benefits was based on the measurements of DBH made in 2009. Trunk diameter was measured with a diameter tape in inches at $1.3 \mathrm{~m}$. Height and branch spread were measured in feet in 2009. Height was measured using a Model 200, TruPulse $^{\mathrm{TM}}$ laser rangefinder (Laser Technology, Centennial, Colorado, U.S.), in feet. Branch spread was measured along the axis of the road using the same laser rangefinder. The survival rate was estimated by dividing the number of surviving trees by the estimated number of possible planting sites in 2007 and in 2009. Obvious replacement trees and open sites were counted as missing for the purpose of determining survival rates on the two streets.

Morton Ave. contained 75 trees from the original planting while Orchard Grove had only 11. Thus ten trees from each population of trees on the two streets were selected at random for inclusion in the study and analysis.

The algorithms in i-Tree Streets use look-up tables in size ranges and were too coarse to discern differences since differences in diameter were small as a result of site uniformity (Table 1). Environmental benefits were plotted and the underlying algorithms were recovered and used to evaluate the trees individually in each of the two planting sites in Brooklyn, $\mathrm{OH}$, and to describe and quantify the values of environmental and aesthetic benefits.

On, Morton Ave. 75 Sunburst honeylocust trees of the original 84 trees had an estimated survival rate of $89 \%$. While on Orchard Grove, only 17 trees appear to have been planted and 11 still remain, giving a $65 \%$ survival rate for hawthorn. The survival rates for honeylocusts are similar to six other honeylocust sites in the OSTEP study (avg. 76\%). Survival rate for the Lavalle hawthorn on Orchard Grove was higher than in five other sites (avg. 31\%) but this was the only site with similar site conditions to the larger growing honeylocusts (Sydnor, et al. 2010). Thus individual i-Tree Streets calculations, using the recovered algorithms were adjusted to $89 \%$ survival (multiplied by 0.89 ) for trees for Morton Ave. and $65 \%$ for Orchard Grove trees, accounting for the different survival rates for the two species and sites over the 46 years since the initial plantings.

A two sample t-test was performed on the computed environmental benefits for each tree species to test for significance between larger and smaller trees using Minitab 15 (Minitab, Inc., State College, Pennsylvania). An alpha level of 0.05 was used.

\section{RESULTS AND DISCUSSION}

\section{Observations}

In U.S. studies, when residents were asked about characteristics they value in their street trees, respondents suggested characteristics associated with larger trees, such as the ability to canopy the street and shade their homes (Schroeder and

Table 1. Height, caliper and spread of two tree species planted in Brooklyn, $\mathrm{OH}$, after 46 growing seasons in the landscape. A random sample of ten trees was measured for each of the two sites.

\begin{tabular}{|c|c|c|c|c|c|c|}
\hline & \multicolumn{3}{|c|}{ Hawthorn } & \multicolumn{3}{|c|}{ Honeylocust } \\
\hline & $\begin{array}{l}\text { Caliper } \\
\mathrm{cm} \text { (in) }\end{array}$ & $\begin{array}{c}\text { Height } \\
\text { m (ft) }\end{array}$ & $\begin{array}{c}\text { Spread } \\
\text { m (ft) }\end{array}$ & $\begin{array}{l}\text { Caliper } \\
\mathrm{cm} \text { (in) }\end{array}$ & $\begin{array}{c}\text { Height } \\
\text { m (ft) }\end{array}$ & $\begin{array}{l}\text { Spread } \\
\text { m (ft) }\end{array}$ \\
\hline Mean & 34.5 (13.6) & $7.4(24.3)$ & $7.7(25.3)$ & $51.5(20.3)$ & $15.3(50.2)$ & $13.7(45.0)$ \\
\hline Std error & $6.2(2.4)$ & $1.0(3.3)$ & $1.1(3.6)$ & $2.8(1.1)$ & $1.4(4.6)$ & $1.1(3.6)$ \\
\hline
\end{tabular}


Ruffolo 1996; Heimlich et al. 2008). Rarely were street trees rated as too big. This does not carry over to the United Kingdom with their lower light levels and cooler summer temperatures, where smaller trees were valued (Schroeder et al. 2006). This study set out to value environmental benefits of a larger growing species versus a smaller growing one when adjusted for survival rates after 46 growing seasons (years) in the landscape.

These two taxa were chosen, in part, for their different sizes at maturity. Hawthorns had reached $7.4 \mathrm{~m}$ while the honeylocusts reached $15.3 \mathrm{~m}$ within 46 growing seasons (Table 1). Neither site had overhead utility lines thus trees had not been pruned for overhead utilities but both sites had been pruned to ensure clearance for roadways and sidewalks.

Caliper (DBH) is used by i-Tree Streets as a surrogate for canopy volume or size, and incorporates both height and width. The mean DBH for hawthorn was $34.5 \mathrm{~cm}$ and the mean DBH for honeylocust was $51.5 \mathrm{~cm}$ (Table 1).

Visual comparisons of growth attributes can be seen in Figure 1. Morton Avenue had a canopied street while Orchard Grove did not. Anecdotally, it appeared that more people and children were outside on Morton when visited by researchers on a sunny day in July 2007. People came out to see what the study authors were doing as they measured the trees, while people had a tendency to look out the windows on Orchard Grove. Researchers did not try to characterize these observations in this study, but they seem consistent with observations by Kuo (2001).
Environmental benefits are separated into five categories, including energy conservation, air quality improvement, $\mathrm{CO}_{2}$ benefits, stormwater control, and property value increases (Maco and McPherson 2003) for reporting in i-Tree Streets. The various environmental benefits will be considered individually.

\section{Benefits}

Stormwater runoff is a major cost for many communities. Columbus, $\mathrm{OH}$, is presently embarking on a 2.5 billion dollar sewer and stormwater separation/upgrade for the community over the next four decades. i-Tree Streets assumes that water intercepted would otherwise be retained in retention basins or treated as sewerage.

Stormwater benefits varied greatly between tree sizes. The hawthorns on Orchard Grove would have intercepted storm water and saved Brooklyn, OH, USD \$15 per tree in 2009. This is in stark contrast to the honeylocusts on Morton Ave., which would have intercepted five times the amount of storm water, saving Brooklyn, $\mathrm{OH}, \$ 83$ dollars per surviving tree (Table 2).

Stored carbon, as reported in this study, represents the value of carbon removed from the air and stored in these street tree plantings during the 46 years since planting in Brooklyn (Table 3). More than eight dollars worth of stored carbon exists in each surviving honeylocust tree. This is 3.5 times greater than for surviving hawthorns.

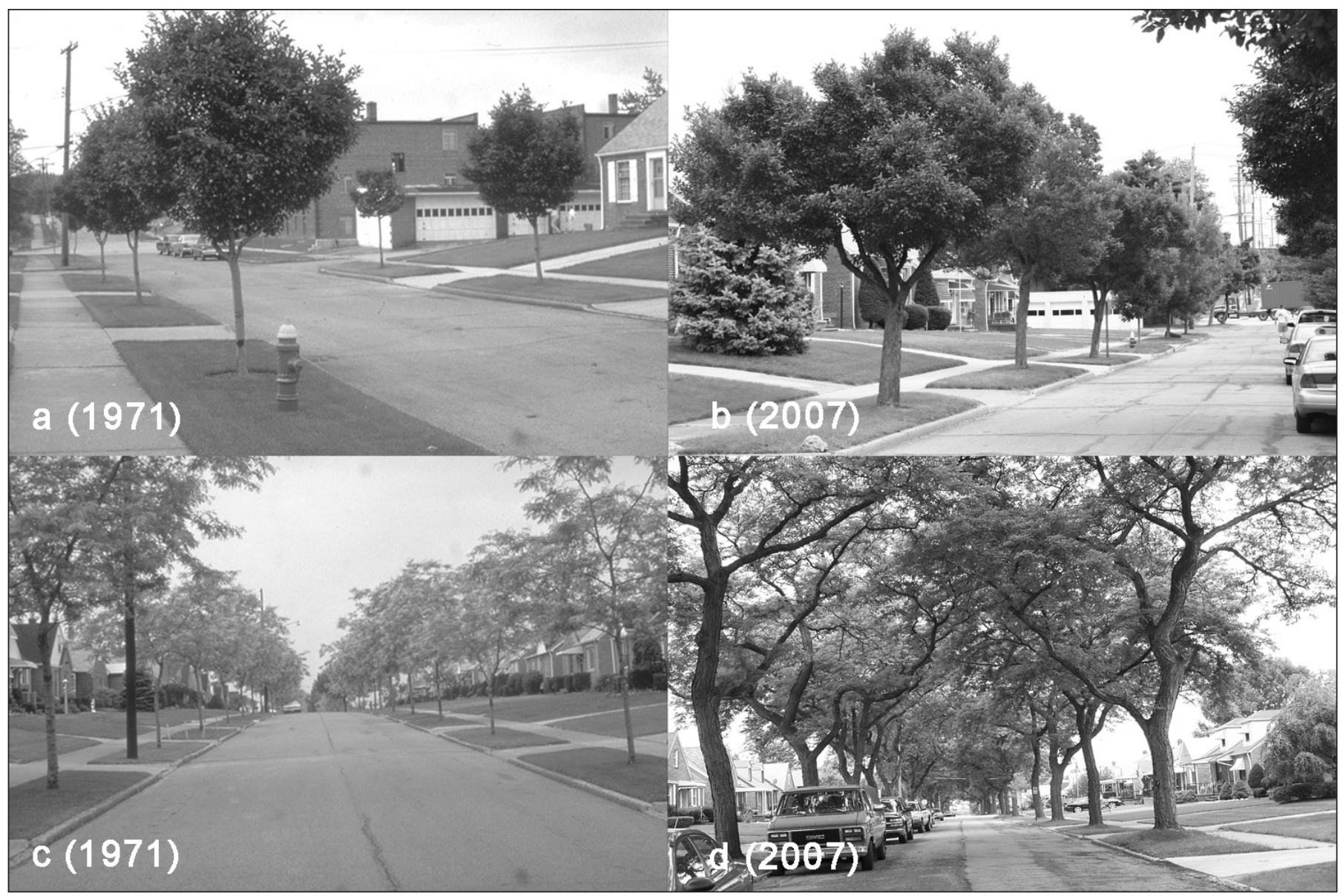

Figure 1. a-b) Orchard Grove, planted with Lavalle hawthorn is on the top, and c-d) Morton Avenue, planted with Sunburst honeylocust is on the bottom. Photos were taken in the years noted on each photograph. 
Annual carbon benefits for 2009 include both the amount of carbon sequestered during a growing season as well as avoided carbon (carbon which was not produced by a power plant in producing energy). Avoided carbon is nearly twice as great for honeylocust when compared to hawthorn. Annual carbon sequestration can lead to carbon credits that can be marketed if the carbon credits are above an established background level (Maco and McPherson 2003). The honeylocust trees sequestered and avoided (data not shown) $\mathrm{CO}_{2}$ credits worth $\$ 10$ per surviving tree for 2009 (Table 2) if a carbon trading system was in place and if a system for accounting for them were available for community trees. Hawthorns, because of their smaller size and lower survival, sequestered and avoided only $\$ 3$ worth of potential carbon credits per surviving tree. The honeylocusts produce 3.3 times the benefit. The dollar figures are net gain figures and include deductions maintenance, such as deducting for the $\mathrm{CO}_{2}$ given off during pruning. Obviously annual $\mathrm{CO}_{2}$ benefits vary by species and size and are a predictable benefit that could be optioned for when a tree selection for a community planting is made.

Air quality normally has smaller costs savings in dollars than most other benefits measured but may have much greater impacts on the quality of life for residents with asthma, for example. Annual air quality savings include reduced ozone, nitrous and sulfur oxides, as well as particulate matter. These benefits include both direct savings from the trees and avoided pollution. Avoided pollution is pollution not generated at a power source because energy was not required by the community. The values generated were discounted for biogenic volatile organic compounds (BVOC) that are given off by trees, such as the smell of a pine forest. Surviving honeylocusts would have delivered \$11 in annual benefits per tree in 2009 (Table 2). Again hawthorns are smaller and have a reduced impact with a net reduction in pollutants worth $\$ 5$ in 2009. This benefit per tree for honeylocust is 2.2 times that of hawthorn after 46 years.

Energy savings by trees are exceptionally important in view of the citizenry's increasing concern over the United States' energy dependency. Planting trees in our communities is thought to be more cost effective than building power plants as an alter- native to meeting our energy needs. The Sacramento Municipal Utility District (SMUD) has partnered with the Sacramento Tree Foundation to provide as many as ten, deciduous trees per SMUD residential customer to shade residences, at no cost (Anonymous 2009). Energy is saved by shading structures, evaporating water (evapotranspiration), and reducing wind speed around structures (McPherson et al. 2006). A honeylocust in 2009 would have saved the community $\$ 63$ per tree in electricity and natural gas (Table 2). In contrast, a planting of the smaller and generally shorter lived hawthorns (Sydnor et al. 2010) is estimated to have saved the community \$26 in electricity, and natural gas. The honeylocust planting is estimated to result in energy savings approximately 2.4 times greater than the hawthorns when adjusted for survival.

Direct economic benefits, such as increased real estate values in i-Tree, use hedonic property values. These values are also used as a surrogate for social benefits such as increased community pride. Increased property values accrue and improve over time if trees are properly maintained (McPherson et al. 2006). Research in public housing has shown that areas with trees facilitate interaction among residents and lead to reduced domestic violence and more sociable environments (Kuo 2001). Surveys suggest that customers prefer to spend their money and time in commercial streetscapes with trees and may be willing to spend more in commercial settings with trees (Wolf 2003). Honeylocusts are estimated to contribute $\$ 219$ per surviving tree in 2009 to the community in the form of enhanced community identity among other things (Table 2). Hawthorns are estimated to have contributed only $\$ 14$ per tree to the community. If we were to consider only the two different trees, the honeylocust deliver 15.6 times the annual aesthetic benefits than hawthorn or $93 \%$ of the aesthetic benefits of the two trees together.

Energy and stormwater benefits for 2009 are larger than air quality and carbon sequestration benefits but are still smaller than the impact on aesthetics, including property values. Carbon sequestration and air pollution reduction are the smallest of annual benefits, yet can be exceedingly important for individuals who might be sensitive to something such as soot $\left(\mathrm{PM}_{10}\right)$, which causes great difficulty for asthmatics. Should researchers be able

Table 2. Environmental benefits for surviving trees of two species of trees in Brooklyn, $\mathrm{OH}$, for 2009 are presented in U.S. dollars per tree.

\begin{tabular}{|c|c|c|c|c|c|}
\hline \multirow[t]{2}{*}{ Annual benefits } & \multicolumn{2}{|c|}{ Hawthorn } & \multicolumn{2}{|c|}{ Honeylocust } & \multirow[t]{2}{*}{$P$ value @ $0.05^{y}$} \\
\hline & mean $\$ /$ tree & $\mathrm{SE}^{\mathrm{z}}$ & mean $\$ /$ tree & $\mathrm{SE}^{\mathrm{z}}$ & \\
\hline Energy & $\$ 26$ & 0.98 & $\$ 63$ & 0.49 & .00001 \\
\hline $\mathrm{CO}_{2}$ & $\$ 3$ & 0.06 & $\$ 10$ & 0.02 & .00001 \\
\hline Air quality & $\$ 5$ & 0.19 & $\$ 11$ & 0.10 & .00001 \\
\hline Storm water & $\$ 15$ & 0.79 & $\$ 83$ & 1.40 & .00001 \\
\hline Aesthetic/other & $\$ 14$ & 0.17 & $\$ 219$ & 0.91 & .00001 \\
\hline Total & $\$ 57$ & 2.40 & $\$ 430$ & 3.40 & .00001 \\
\hline
\end{tabular}

${ }^{\mathrm{z}}$ Standard error of mean.

${ }^{y}$ Probability of differences between hawthorn and honeylocust means.

Table 3. Stored $\mathrm{CO}_{2}$ includes the carbon stored over 46 growing seasons. Values are provided in U.S. dollars per tree for two species of trees on the streets in Brooklyn, $\mathrm{OH}$.

\begin{tabular}{|c|c|c|c|c|c|}
\hline Species & $\begin{array}{l}\text { Stored carbon } \\
\quad \$ / \text { tree }\end{array}$ & $\mathrm{SE}^{\mathrm{z}}$ & $\begin{array}{l}\text { Avoided carbon } \\
\quad \$ / \text { tree }\end{array}$ & $\mathrm{SE}^{\mathrm{z}}$ & $P$ value @ $0.05^{\mathrm{y}}$ \\
\hline Lavalle hawthorn & $\$ 2.44$ & 0.63 & $\$ 2.32$ & 0.22 & 0.0000 \\
\hline Sunburst honeylocust & $\$ 8.46$ & 0.79 & $\$ 4.38$ & 0.08 & 0.0000 \\
\hline
\end{tabular}

${ }^{\mathrm{z}}$ Standard error of mean

y Probability of differences between hawthorn and honeylocust means. 
to define base levels of annual carbon sequestration for a community, additional carbon sequestration might allow communities to sell carbon credits. When all 2009 benefits are included, the honeylocusts are estimated to contribute $\$ 430$ per surviving tree to the community (Table 2). In contrast, the surviving hawthorns contribute $\$ 57$ per tree. Thus, total air quality benefits for hawthorns are 7.5 times higher than those of hawthorns in 2009.

\section{CONCLUSION}

i-Tree Streets is used here to contrast the environmental benefits of a large and a small growing species in Brooklyn, $\mathrm{OH}$, growing in similar sites. Accordingly, trees are assumed to be representative of their respective species, in two size categories, in an average street tree location, with average cardinal orientation and distances to structures. In other words, results would vary if one were to optimize a location for a benefit such as shading to decrease heating and cooling costs for a specific site.

Mature size and longevity are major factors in determining environmental benefits. In this study, reducing survival from $89 \%$ (honeylocust) to $65 \%$ (hawthorn) results in the loss of $27 \%$ of the benefits that would have accrued to the hawthorn if the trees had an 89\% survival rate in 2009 .

When making decisions for a community, it sometimes helps to consider things on a larger scale. Suppose the Brooklyn, OH, urban foresters in 1964 had been able to plant 100 trees of both types in the same location with the same results. There would then be 89 surviving honeylocusts and 65 surviving hawthorns. The hawthorns would then be delivering a total of $\$ 5,700$ for the community while the honeylocusts would be delivering 7.5 time as much, or $\$ 43,000$.

If another scenario is used and the hawthorns were spaced 6.1$7.6 \mathrm{~m}$ on center, one could then double the number of trees but their survival rate would remain the same. Some communities do this when planting smaller trees. In this scenario, the larger, longer lived honeylocusts would still produce 3.8 times as many environmental benefits as the smaller growing hawthorns after 46 years in the landscape. This study clearly demonstrates that, where space is available, such as in the two sites selected, larger, and longer lived street species will benefit the community in a variety of ways.

This study should not be construed to suggest the use of larger growing trees beneath utility lines as utility pruning is expensive, causes conflicts, and can interrupt utility service. Utilities generally prune plants to no more than $7.6 \mathrm{~m}$ high beneath utility lines, which reduces the service life and environmental benefits of trees. Utility pruned trees were not considered in this simulation as utility lines were not present in either site. One must still cite trees properly and use various taxa, but mature size, longevity, and potential environmental benefits should be considered when planning urban plantings.

\section{LITERATURE CITED}

Anonymous. 2009. Sacramento Tree Foundation. Accessed July 9, 2009. $<$ http://www.sactree.com/doc.aspx?25>

Anonymous. 2006. iTree: Tools for managing and assessing Community Forests. Accessed May17, 2009. <http://www.itreetools.org/>

Kuo, F.E. 2001. Coping with poverty: Impacts of environment and attention in the inner city. Environment and Behavior 33:5-3

Heimlich, J.E., T.D. Sydnor, M. Bumgardner, and P. O'Brien. 2008. Attitudes of residents toward street trees on four streets in Toledo, Ohio, U.S. before removal of ash trees (Fraxinus spp.) from emerald ash borer (Agrilus planipennis). Arboriculture \& Urban Forestry 34(1):47-53.

Maco, S., and G. McPherson. 2003. A practical approach to assessing structure, function, and value of street tree populations in small communities. Journal of Arboriculture 29:84-97.

McPherson, E.G., J.R. Simpson, P.J. Peper, S.E. Maco, S.L. Gardner. S.K.Cozad, and Q. Xia. 2006. Midwest Community Tree Guide. United States Department of Agriculture Forest Service, Pacific Southwest Research Station General Technical Report PSW-GTR-199. 100 pp.

McPherson, E.G. 2005. Trees with benefits. American Nurseryman 201:34-40

Reisch, K.W., G. Hull, and H.M. Hill. 1971. Case Histories of Several Street Tree Species and Cultivars at Selected Sites in Five Ohio Cities. Horticulture Series 376. Ohio Agricultural and Development Center, Wooster, OH. 65 pp.

Santamour, F.S., Jr. 1990. Trees for urban planting: Diversity, uniformity and common sense. Proceedings of the 7th Conference of the Metropolitan Tree Improvement Alliance (METRIA) 7:57-65.

Schroeder, H.W., and S.R. Ruffolo. 1996. Householder evaluations of street trees in a Chicago suburb. Journal of Arboriculture 22:35-43

Schroeder, H., J. Flannigan, and R. Coles. 2006. Residents' Attitudes toward Street Trees in the UK and U.S. Communities. Arboriculture \& Urban Forestry 32:236-246.

Sydnor, T.D., S. Subburayalu, J. Chatfield, E. Draper, A. Stone, K. Smith, and J. Conglose. 2010. Street Tree Evaluation Project: Forty Years of Street Tree Evaluation in Five Communities. Ohio State University Extension Bulletin \#877. Columbus, OH. 100 pp.

Wolf, Kathleen L. 2003. Public response to urban forest in inner-city business districts. Journal of Arboriculture 29:117-126.

\section{T. Davis Sydnor}

Professor of Urban Forestry

School of Environment and Natural Resources

The Ohio State University

2021 Coffey Road

Columbus, OH 43210-1085, U.S.

sydnor.1@osu.edu

Sakthi K. Subburayalu

Post-doctoral Researcher

School of Environment and Natural Resources

The Ohio State University

2021 Coffey Road

Columbus, OH 43210-1085, U.S. 
Résumé. Le Projet d'Évaluation des Arbres d'Ornement de l'Ohio a débuté en 1965. Deux des plantations originales à Brooklyn en Ohio incluaient 17 aubépines de Lavallée (Crataegus $\times$ lavallei Hérincq ex. Lavallee) à petit déploiement et 84 féviers inermes (Gleditsia triacanthos L. 'Sunburst') à grand déploiement. Une des conséquences découlant du choix des arbres provient des valeurs différentes de bénéfices environnementaux générés par des arbres de dimension et de taux de survie différents. Les valeurs de bénéfices environnementaux n'ont pas été prises en compte à l'origine lors du choix des espèces, mais elles peuvent maintenant être calculées au moyen du logiciel $i$-Tree.

Les algorithmes contenus dans le logiciel $i$-Tree Streets ont été utilisés pour calculer les bénéfices environnementaux de dix des arbres choisis au hasard parmi chacune des deux plantations à Brooklyn en Ohio, valeurs qui ont été ajustées en fonction des taux de survie, $89 \%$ pour les féviers sur Morton Avenue et 65\% pour les aubépines sur Orchard Grove. Lorsque ajusté en fonction du taux de survie, les féviers fournissaient 430 \$ US en bénéfices par arbre tandis que les aubépines affichaient une valeur moyenne de 57 \$ par arbre. Lorsque qu' analysé sur la base du taux de survie, les féviers donnaient 7,5 fois plus de bénéfices que les aubépines. Quel que soit l'angle avec lequel on regarde le tout, on constate qu'il y a une diminution significative des bénéfices environnementaux obtenus à partir d'arbres à petit déploiement, et ce par rapport à des arbres à grand déploiement. Les municipalités devraient prendre en considération cet aspect lorsque l'espace disponible s'avère suffisant pour planter des arbres à plus grand déploiement.

Zusammenfassung. In 1965 gegann in Ohio das Projekt zur Bewertung von Schattenbäumen. Zwei der Original-Pflanzungen in Brooklyn bestanden aus 17 kleinwüchsigen (Crataegus $\times$ lavallei Hérincq ex. Lavallee) und 84 größer wachsenden (Gleditsia triacanthos L. Sunburst). Eine Konsequenz aus der Selektion von Bäumen sind die abweichenden Werte ökologischer Vorteile, die durch Bäume von verschiedenen Größen und Überlebensraten. Die Werte ökologischer Vorteile wurden bei der Pflanzenauswahl nicht berücksichtigt, aber die freie Software i-Tree ermöglicht nun, diese mit einzubeziehen.
Die Algorithmen aus der i-tree-software wurden verwendet um die ökologischen Vorteile von zehn, zufällig ausgewählten Bäumen innerhalb jeder der zwei Pflanzungen in Brooklyn, Ohio zu bewerten und für die Überlebensraten anzupassen, $89 \%$ in der Morton Avenue bei den Gleditschien und $65 \%$ bei den Weißdornen. Nach der Anpassung lieferten die Gleditschien pro Baum \$340 an monetärem Gegenwert der öklogischen Vorteile gegenüber $\$ 57$ bei den Weißdornen. Wenn es auf der Basis des pro einzelnen überlebenden Baumes berechnet wurde, lieferten die Gleditschen das 7,5-fache an ökologischen Vorteilen. Unabhängig wie es betrachtet wird, gibt es eine signifikante Minderung der ökologischen Vorteile wenn kleinwüchsige Bäume im Vergleich zu größeren verwendet werden. Die Kommunen sollten diesen Aspekt bedenken, wenn Platz für größere Bäume verfügbar ware.

Resumen. El proyecto de evaluación de árboles de sombra de Ohio, US, empezó en 1965. Dos de las plantaciones originales en Brooklyn, Ohio incluyeron 17 arbolitos (Crataegus $\times$ lavallei Hérincq ex. Lavallee) y 84 árboles grandes (Gleditsia triacanthos L. Sunburst). Una consecuencia de la selección de los árboles son los diferentes valores de beneficios ambientales generados por los tamaños de árboles y las tasas de sobrevivencia. Los valores de beneficios ambientales no han sido considerados en la selección de la planta pero el software gratuito i-Tree nos permite calcularlo. Fueron utilizados los algoritmos recobrados de i-Tree para calcular los beneficios ambientales en diez árboles seleccionados al azar en cada una de las dos plantaciones en Brooklyn, Ohio, US. Se ajustaron las tasas de supervivencia 89\% en Morton Avenue para los árboles grandes y $65 \%$ para los chicos plantados en Orchard Grove. Cuando se ajustaron para supervivencia, los Gleditsia rindieron \$430 USD por árbol en beneficios en contraste a los $\$ 57$ por árbol de Crataegus. Desde el punto de vista de la supervivencia, los Gleditsia dan más de 7.5 veces beneficios ambientales. Independiente de lo visto aquí hay una reducción significativa en beneficios ambientales cuando se usan árboles pequeños comparados con árboles grandes. Las comunidades deberían consideran este aspecto cuando estén disponibles grandes espacios para árboles. 